\title{
Phytochemistry and Larval Toxicity of Ipomea asarifolia, Commelina diffusa, Acalypha ciliata and Eleusine indica against Artemia salina
}

\author{
Akouavi CC Adoho ${ }^{1,2,3}$, Basile B S Konmy ${ }^{1}$, Pascal A Olounladé ${ }^{1,2,3^{*}}$, Erick VB Azando ${ }^{2,3,4}$, Mawulé \\ S Hounzangbé-Adoté ${ }^{2}$ and Armand B Gbangboché ${ }^{1,3}$
}

\begin{abstract}
${ }^{1}$ Biochemistry and Pharmacognosy Division, Unit of Zootechnics and Livestock System Research, Laboratory of Animal and Fisheries Sciences, National University of Agriculture, 01 BP 55, Porto-Novo, Benin; ${ }^{2}$ Laboratory of Ethnopharmacology and Animal Health, Faculty of Agronomics Sciences, University of Abomey-Calavi, 01 BP 526 Cotonou, Benin; ${ }^{3}$ Laboratory of Biotechnology and Animal Improvement, Institute of Applied Biomedical Sciences, Faculty of Agronomics Sciences, University of Abomey-Calavi, 01 BP 526 Cotonou, Benin; ${ }^{4}$ Research Laboratory on Vector, Host and Pathogen Interactions, Department of Animal and Fisheries Production Sciences and Techniques, Faculty of Agronomy, University of Parakou, BP 123, Parakou, Benin

*Corresponding author: abiodouno@yahoo.fr
\end{abstract}

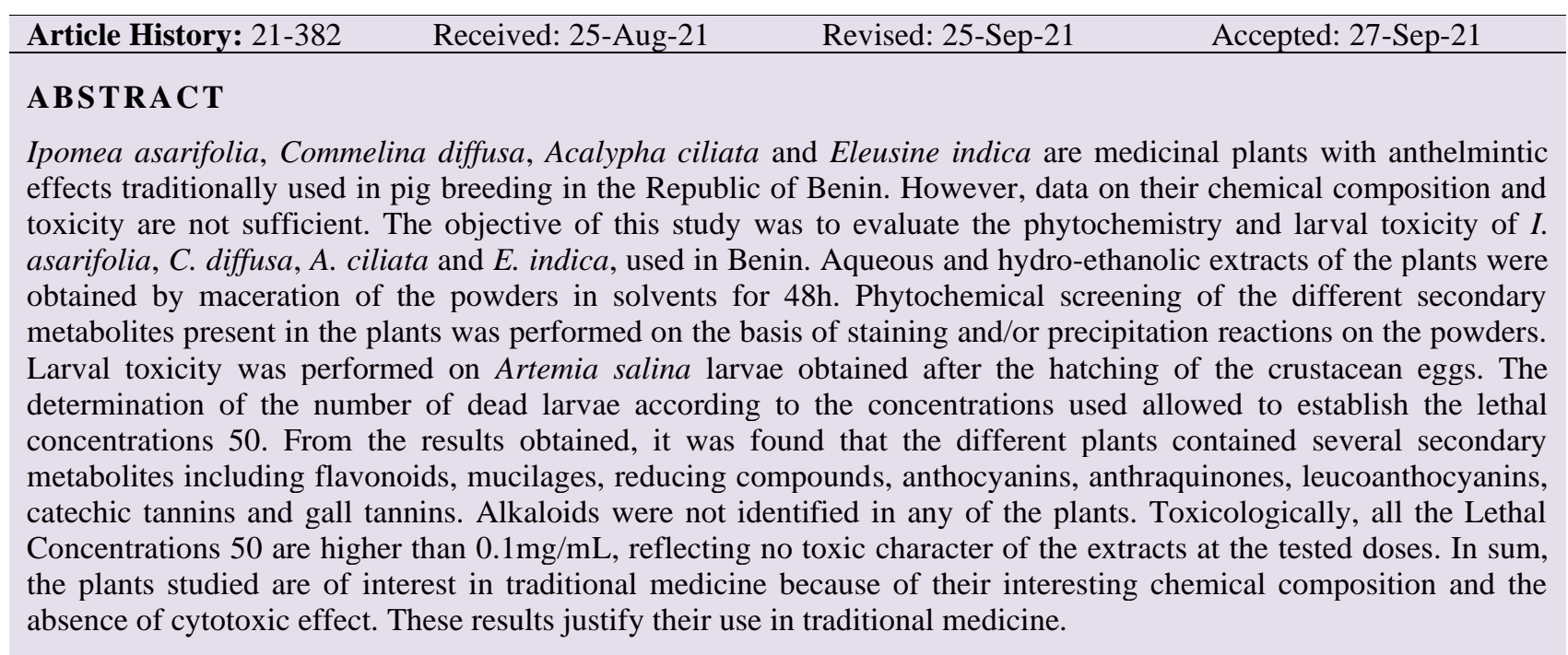

Key words: Phytochemical screening, Medicinal plants, Cytotoxicity and Traditional medicine

\section{INTRODUCTION}

The use of medicinal plants in the traditional management of various human diseases is a common practice worldwide (Mounanga et al. 2015; Elghobashy et al. 2020). Today, medicinal plants still represent the primary source of therapeutic substances especially in developing countries for primary health care (Tine et al. 2019; Rafay et al. 2021). Knowledge of their virtues and risks has been built on traditional beliefs specific to each culture (Biu et al. 2016). They have evolved, empirically over centuries of experience. In many countries, especially the less developed ones, many people depend on traditional consultants and their treatment methods based on the use of medicinal plants to meet health care needs (Hosseinzadeh et al. 2015; Olusunle et al. 2019). In sub-Saharan Africa, traditional herbal medicine is an alternative to modern chemical and industrial drugs and is widely used in both rural and urban areas (Angone et al. 2013). In addition, there is a good deal of literature on the effectiveness of many of these traditional herbal medicines (Angone et al. 2013). Medicinal plants are used both in human and animal species for beneficial effects. The effectiveness of plants is attributed to the secondary chemical groups present in these plant species (Mohan et al. 2021). Among these chemical groups responsible for the various biological properties of medicinal plants are alkaloids, flavonoids, saponins, steroids, terpenoids, polysaccharides and tannins (Mahboubi et al. 2013).

Cite This Article as: Adoho ACC, Konmy BBS, Olounladé PA, Azando EVB, Hounzangbé-Adoté MS and Gbangboché $\mathrm{AB}, 2022$. Phytochemistry and larval toxicity of Ipomea asarifolia, Commelina diffusa, Acalypha ciliata and Eleusine indica against Artemia salina. International Journal of Veterinary Science 11(2): 121-128. https://doi.org/10.47278/journal.ijvs/2021.098 
In Benin, medicinal plants are widely used against animal diseases. An ethno-pharmacological survey conducted in Benin on medicinal plants used against intestinal parasites of pigs revealed several plant species including I. asarifolia, C. diffusa, A. ciliata and E. indica. Pig farmers in Benin have claimed with high citation frequency on the efficacy of these plants on intestinal parasites of pigs (Adoho et al. 2021). In traditional medicine, I. asarifolia has many medical uses throughout West Africa. It is used for stomach problems, Guinea worm infections, wounds, postpartum hemorrhage, tetanus, meningitis, and intestinal worms (Farida et al. 2012). A. ciliata is used for eye infections, infected wounds, asthma, stomach aches, intestinal worms and many other diseases (Singh et al. 2004). In Madagascar, the ground aerial parts are applied to dislodge parasites from the skin and is also used as a dewormer (Singh et al. 2004). C. diffusa is commonly used against urinary and respiratory infections, diarrhea, hemorrhoids, enteritis, and eye problems such as ophthalmia, conjunctivitis and many other diseases (Khan et al. 2011). Regarding E. indica, it is used against insect bites, fever and convulsions (Al-Zubairi et al. 2011). The decoction is applied against boils and stomach problems (Al-Zubairi et al. 2011). In addition, some studies have shown the pharmacological properties of these plants. For example, work by Alkali et al. (2015) shows that $I$. asarifolia has good trypanocidal activity on Trypanosoma evansi. Jegede et al. (2009) and Furtado et al. (2016) attributed the biological properties of this plant to the presence of certain secondary groups including phenolic compounds.

Some previous phytochemical studies show the presence of glycoside, flavonoid, sterol, terpenoids, tannin, alkaloid and anthraquinones in C. diffusa (Nasrin et al. 2019). According to the work of Okoronkwo et al. (2015), A. ciliata is rich in several chemical groups such as alkaloids, tannins, saponins and mineral compounds namely calcium, magnesium, iron, phosphorus and sodium. It also has good antibacterial activity (Odeja et al. 2016). Several studies have also highlighted the biological properties and phytochemical composition of E. indica (AlZubairi et al. 2011; Morah and Odey 2020). Toxicologically, it has been established that the majority of medicinal plant extracts do not show toxicity at the tested doses (Nasrin et al. 2019). Although medicinal plants are presented as natural and harmless products, they can cause toxic effects, especially if taken in excessive doses, or if they interact with conventional drugs (Lakmichi et al. 2010; Neergheen-Bhujun 2013). The experiments of nanotoxicity, larval toxicity and aquatic toxicity are carried out with species of the genus Artemia sp, which has been accepted as a reliable organism. This has allowed the ISO TS 20787 standard to standardize the nanotoxicity tests with Artemia sp (Lish et al. 2019). The brine shrimp Artemia salina is widely used for toxicity testing because of its wide distribution, short life cycle, non-selective feeding, and sensitivity to toxicants (Neves et al. 2017). Artemia salina is a species now used in toxicity assessment because it provides a valid method for assessing the cytotoxicity of plant extracts (Unuofin et al. 2017). Therefore, A. salina seems to be a suitable model species for assessing the toxicity of medicinal plants. Thus, research focused on the phytochemical composition of medicinal plants and their potential toxicities is strongly encouraged by many medical organizations and by complementary and alternative medicine researchers (Cooper 2004; Ghorani-Azam et al. 2018).

Despite their frequent use for therapeutic purposes, data related to their phytochemical constituents and their toxicity are insufficient, especially in the Beninese context. Moreover, according to (Badiaga 2011), the phytochemical constituents of medicinal plants vary from one region to another, depending on the location, the nature or the nutritional richness of the soil and the climate. The frequent use of these plants on pigs could disrupt the normal functioning of the organs. This study was initiated in this context to fill this gap. It aims to evaluate the phytochemistry and larval toxicity of Ipomea asarifolia, Commelina diffusa, Acalypha ciliata and Eleusine indica, used in Benin. These data will constitute a strong added value to the valorization of these medicinal plants. They will allow us to understand their biological activities and to ensure their safety.

\section{MATERIALS AND METHODS}

\section{Plant Material}

The plant material used consisted of leaves of $I$. asarifolia and whole plants of A. ciliata, C. diffusa and E. indica collected in the commune of Abomey-Calavi, South Benin on October 1, 2020 and authenticated at the National Herbarium of Benin under numbers YH 525/HNB, YH 526/HNB, YH 527/HNB and YH 528/HNB, respectively.

\section{Animal Material}

The animal material consisted of Artemia salina larvae (ARTEMIO JBL D-67141 Gmbh Neuhofem), obtained by putting $10 \mathrm{mg}$ of Artemia salina eggs in $1 \mathrm{ml}$ of sea water. The eggs of Artemia salina were acquired in the trade at JBL society (JBL Gmbh \& Co. KG, Germany).

\section{Plant Extraction}

The collected plants were dried in the laboratory at $18^{\circ} \mathrm{C}$ for two weeks, followed by grinding with a Retsch mill type SM 2000/1430/Upm/Smf. The resulting powder was stored in an airtight jar at room temperature. The aqueous and hydro-ethanol extracts were obtained according to the methodology described by Klotoé et al. (2020). In summary, 50g of powder of each plant was macerated for $48 \mathrm{~h}$ in $500 \mathrm{~mL}$ of distilled water for the aqueous extract and the distilled water-ethanol mixture at $\mathrm{V}-\mathrm{V}$ proportion for the hydro-ethanolic extract. The homogenate obtained was filtered three times on hydrophilic cotton followed by filtration on Wattman No 1 paper (Diameter: $10 \mathrm{~mm}$ and Porosity: 10 $\mu \mathrm{m}$ ). After filtration, the filtrate was collected and evaporated under vacuum using a rotary evaporator. The resulting aqueous phase was placed in an oven at $45^{\circ} \mathrm{C}$ for 5 days for dry evaporation and then stored in a refrigerator at $4^{\circ} \mathrm{C}$.

\section{Qualitative Phytochemical Characterization of Plant Extracts}

The powders were subjected to different qualitative tests to identify the main secondary metabolites. For this purpose, tube testing procedures based on staining or precipitation reactions as described by Odebiyi and 
Int J Vet Sci, 2022, 11(2): 121-128.

Sofowora (1978) were used depending on the metabolites or the family of the compound to be investigated. The classes of metabolites sought, and the general principles of the characterization reactions used are presented in Table 1.

\section{Larval Toxicity Test}

The toxicity of the extracts was evaluated on A. salina larvae following the methodology described by Agbodjento et al. (2020). The A. salina larvae were obtained by hatching $10 \mathrm{mg}$ of $A$. salina eggs under continuous agitation in 1L of seawater for $48 \mathrm{~h}$. Series of second-order dilutions were made from the stock solution $(20 \mathrm{mg} / \mathrm{mL})$ to obtain an increasing concentration scale. Subsequently, $1 \mathrm{~mL}$ of each diluted solution was added to $1 \mathrm{~mL}$ of seawater containing 16 live larvae. A control solution without the extract was prepared under the same conditions. All solutions were incubated under agitation for 24h. Counting the number of dead larvae in each solution was done under a light microscope. The data (concentration-response) were log-transformed and the $\mathrm{LC}_{50}$ (Lethal Concentration) was determined. To evaluate the larval toxicity of the extract, the correlation grid associating the degree of toxicity with the $\mathrm{LC}_{50}$ was used (Table 2).

\section{Statistical Analysis}

The collected data were entered into the Excel spreadsheet version 2016. For the results of the larval toxicity test, a probit analysis was performed to determine the $\mathrm{LC}_{50}$ with SPSS 17.0 software.

\section{RESULTS}

\section{Yield of the Extraction}

The extraction yield for the studied plants varied depending on the extract and the plant. The best yield was obtained with the aqueous extract of I. asarifolia (34.53\%) followed by the aqueous extract of $E$. indica $(10.11 \%)$. For all the plant species studied, the aqueous extracts gave the best yields except for $C$. diffusa for which the hydroethanolic extract gave a higher yield than the aqueous extract. These results are presented in Fig. 1.

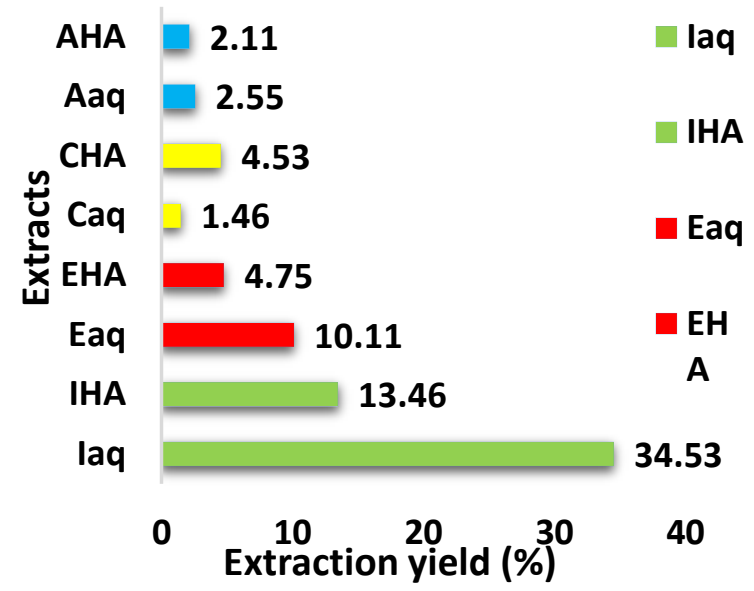

Fig. 1: Extraction yield of Ipomea asarifolia, Eleusine indica, Commelina diffusa and Acalypha ciliate: Legend: Iaq: Aqueous extract of Ipomea asarifolia, IHA: Hydro-ethanolic extract of Ipomea asarifolia, Eaq: Aqueous extract of Eleusine indica, EHA: Hydro-ethanolic extract of Eleusine indica, Caq: Aqueous extract of Commelina diffusa, CHA: Hydro-ethanolic extract of Commelina diffusa, Aaq: Aqueous extract of Acalypha ciliata, AHA: Hydro-ethanolic extract of Acalypha ciliate.

\section{Phytochemical Analysis}

Phytochemical analysis of the four plants studied carried out on the powder of each plant by staining and precipitation reactions revealed the presence of many classes of secondary metabolites. Reducing compounds and anthocyanins are present in E. indica and I. asarifolia respectively. Flavonoids and mucilages were found in all plants while saponosides, cyanogenic derivatives and alkaloids were not present in any of the plants studied. These different data are presented in Table 3. The sign (+) indicates a positive reaction and the sign (-) indicates a negative reaction.

\section{Larval Toxicity}

The sensitivity of $A$. salina larvae to different concentrations of aqueous and hydro-ethanol extracts of the studied plants is presented in Fig. 2, 3, 4 and 5. The results show an increasing mortality of $A$. salina larvae as a function of the concentration of the extracts of the studied plants.

Table 1: General principles of the characterization reactions of the various compounds sought in the extracts of plants.

Secondary metabolite classes Principle of reaction

Tannins

Flavonoids

Anthraquinones

Saponins

Reducing compounds

Steroids

Glycosides

Triterpenoides

Phenolic compounds
Ferric chloride test $\left(\mathrm{FeCl}_{3}\right)$ : With ferric salts, tannins give a dark blue, green or black color.

Schinoda test: soda is added to an aqueous solution of the extract. The appearance of a yellow coloration shows the presence of flavonoids.

Ether test, ammonia: The presence of anthraquinones is indicated by a more or less red coloration of the extract dissolved in ether in the presence of half-diluted ammonia.

Foam test: This is evidenced by the foam index which is provided by the degree of dilution of an aqueous decoction of the drug which, under specified conditions, gives a persistent foam.

After dry evaporation of the aqueous decoctate of the powder, a brick-red precipitate in the presence of Fehling's reagent indicates the presence of reducing compounds.

Liebermann-Buchard test: The presence of steroids is indicated by an intense red colour which turns blue in the extract dissolved in chloroform, after the addition of a few drops of acetic anhydride and concentrated sulfuric acid.

$1 \mathrm{~g}$ of extract is hydrolysed in $5 \mathrm{ml}$ of $5 \% \mathrm{HCl}$, then neutralised with $5 \%$ sodium hydroxide, obtaining a brick red precipitate in the presence of 6 drops of Fehling's reagent indicating the presence of glycosides. The presence of triterpenoids is indicated by an intense red colour that turns dark blue in the extract dissolved in chloroform, after addition of a few drops of acetic anhydride and concentrated sulfuric acid. Ferric chloride $\left(\mathrm{FeCl}_{3}\right)$ test: a small amount of extract dissolved in acid. The addition of a few drops of a ferric chloride solution gives a blue or violet coloration indicating the presence of phenolic compounds. 
Int J Vet Sci, 2022, 11(2): 121-128.

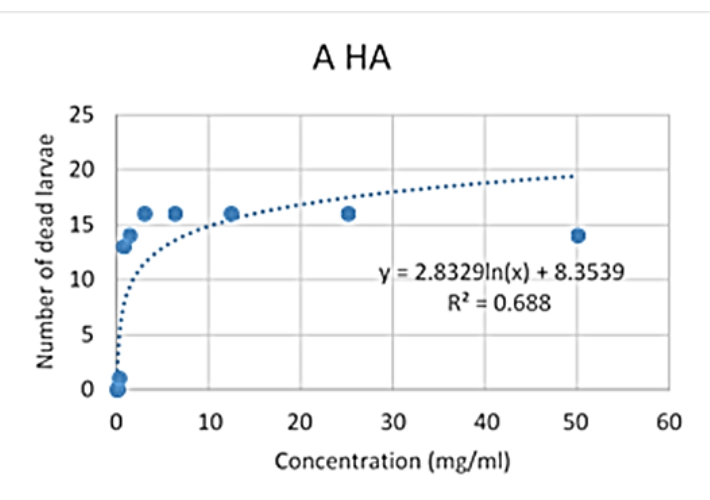

a. Hydro-ethanolic extract

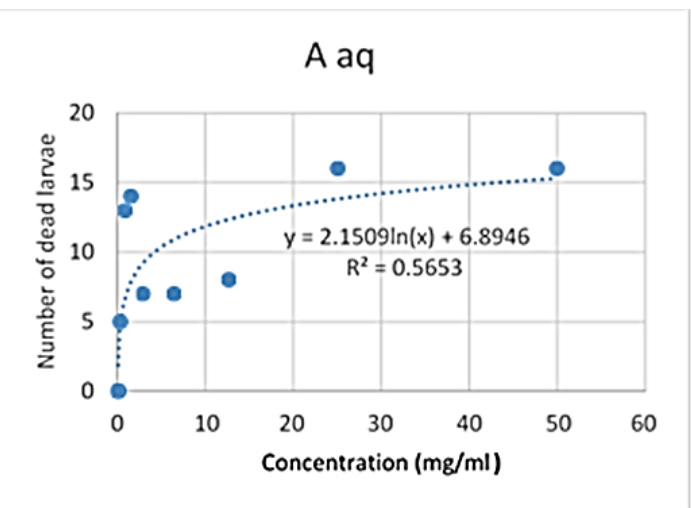

b. Aqueous extract

Fig. 2: Sensitivity of Artemia salina larvae to aqueous and hydro-ethanolic extracts of Acalypha ciliate.

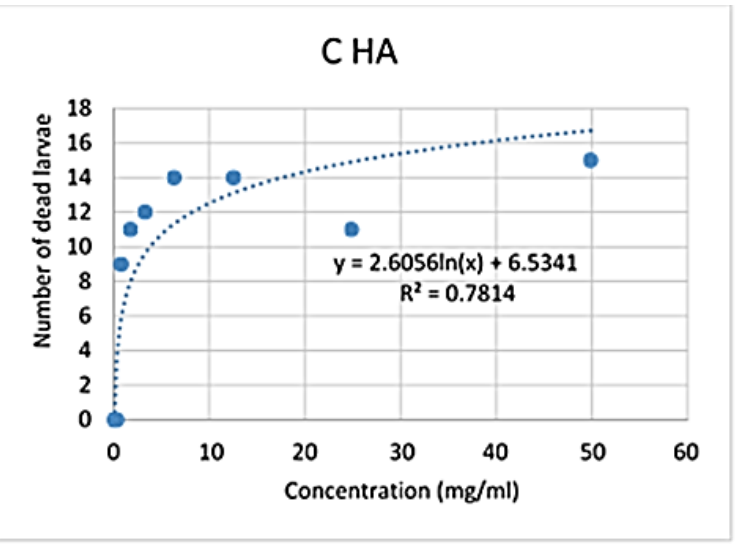

a. Hydro-ethanolic extract

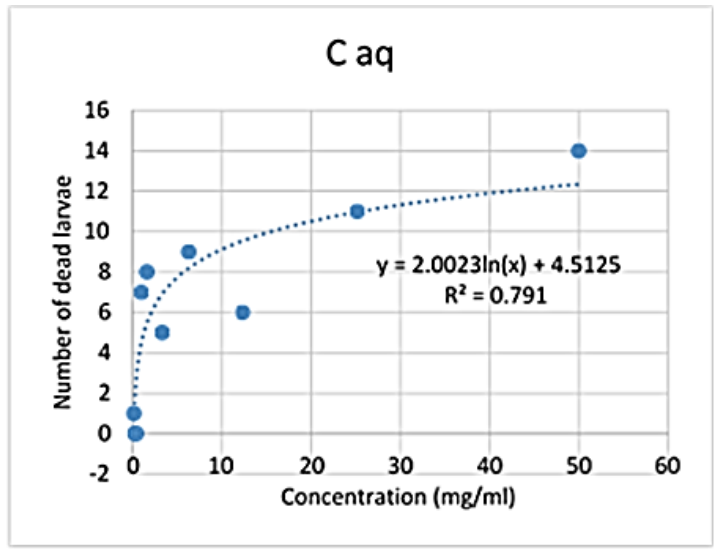

b. Aqueous extract

Fig. 3 : Sensitivity of Artemia salina larvae to aqueous and hydro-ethanolic extracts of Commelina diffusa: C HA=Hydro-ethanolic extract of Commelina diffusa and $\mathrm{C}$ aq=Aqueous extract of Commelina diffusa.

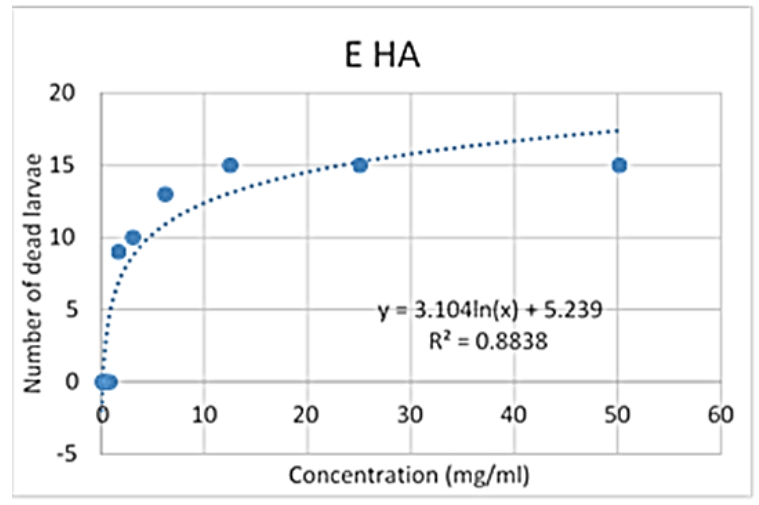

a. Hydro-ethanolic extract

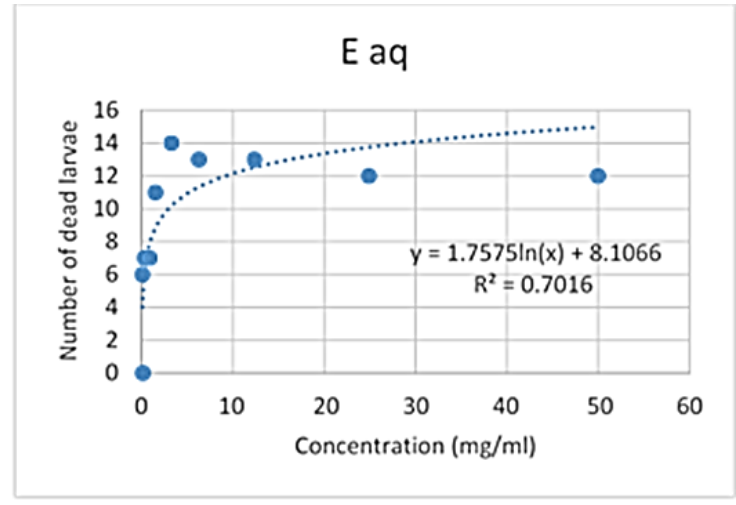

b. Aqueous extract

Fig. 4: Sensitivity of Artemia salina larvae to aqueous and hydro-ethanolic extracts of Eleusine indica. E HA=Hydro-ethanolic extract of Eleusine indica and $\mathrm{E}$ aq=Aqueous extract of Eleusine indica.

\section{DISCUSSION}

The objective of this study was to evaluate the phytochemistry and larval toxicity of I. asarifolia, $C$. diffusa, A. ciliata and E. indica, used in Benin to treat gastrointestinal parasites of pigs.

The extraction yield showed that the aqueous extracts gave the best yields for all plants except $C$. diffusa for which the hydro-ethanol extract gave a better yield compared to the aqueous extract. The highest yields were obtained with the extracts of I. asrifolia. This variability in yields could be explained by the extraction capacity of each solvent. Indeed, the affinity of a solvent for phytomolecules and its polarity influence the extraction yield (DahNouvlessounon et al. 2015). The high yields obtained with water indicate that most of the active ingredients of the plants used are soluble in water and are therefore extractable by this solvent. On the other hand, the work of 
Int J Vet Sci, 2022, 11(2): 121-128.

I HA

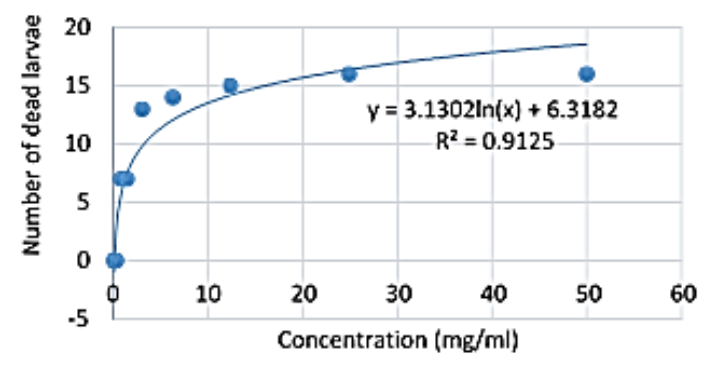

a. Hydro-ethanolic extract

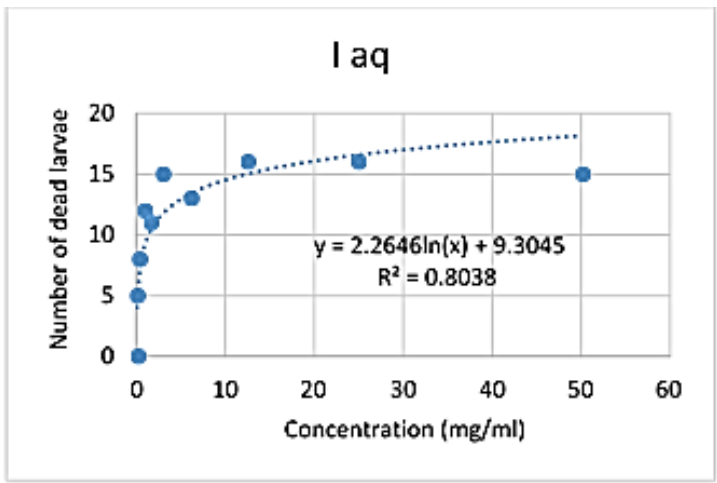

b. Aqueous extract

Fig. 5: Sensitivity of Artemia salina larvae to aqueous and hydro-ethanolic extracts of Ipomea asarifolia. I HA=Hydro-ethanolic extract of Ipomea asarifolia and I aq=Aqueous extract of Ipomea asarifolia: The Lethal concentrations $\left(\mathrm{LC}_{50}\right)$ reported at the comparison scale suggest that at the concentrations tested, the aqueous and hydro-ethanol extracts of the plants studied were not toxic $(\mathrm{LC} 50>0.1 \mathrm{mg} / \mathrm{mL})$

Table 2: Standards used to assess larval toxicity of plant extracts (Moshi et al. 2004).

\begin{tabular}{ll}
\hline LC50 value & Cytotoxicity of the extract \\
\hline $\mathrm{L} C 50 \geq 0.1 \mathrm{mg} / \mathrm{mL}$ & Non-toxic extract \\
$0.1 \mathrm{mg} / \mathrm{mL}>\mathrm{LC}_{50} \geq 0.050 \mathrm{mg} / \mathrm{mL}$ & Low toxicity \\
$0.050 \mathrm{mg} / \mathrm{mL}>\mathrm{LC}_{50} \geq 0.0 \mathrm{mg} / \mathrm{mL}$ & Medium toxicity \\
$\mathrm{LC}_{50}<0.01 \mathrm{mg} / \mathrm{mL}$ & High toxicity \\
\hline
\end{tabular}

Table 3: Classes of secondary metabolites identified in Acalypha ciliata, Commelina diffusa, Eleusine indica and Ipomea asarifolia

Compounds Acalypha Commelina Eleusine Ipomea

\begin{tabular}{lllll} 
& ciliata & diffusa & indica & asarifolia \\
\hline Saponoside & - & - & - & - \\
Cyanogenic & - & - & - & - \\
derivatives & & & & \\
Reducing & - & - & + & - \\
compounds & & & & \\
Anthocyanins & - & - & - & + \\
Anthraquinones & + & + & - & + \\
Leuco-anthocyanins & + & + & - & - \\
Flavonoids & + & + & + & + \\
Mucilages & + & + & + & + \\
Coumarins & - & - & - & + \\
Alkaloids & - & - & - & - \\
Catechic tannins & - & + & - & + \\
Gallic tannins & - & + & - & +
\end{tabular}

Table 4: Values of the Lethal Concentration 50 and the $\mathrm{R}^{2}$ regression coefficients

\begin{tabular}{llll}
\hline Plants & Extracts & $\mathrm{CL}_{50}$ & $\mathrm{R}^{2}$ \\
\hline Acalypha ciliata & Hydro-ethanolic & 0.88 & 0.68 \\
& Aqueous & 1.72 & 0.56 \\
Commelina diffusa & Hydro-ethanolic & 1.76 & 0.78 \\
& Aqueous & 5.72 & 0.79 \\
Eleusine indica & Hydro-ethanolic & 2.44 & 0.88 \\
& Aqueous & 0.94 & 0.70 \\
Ipomea asarifolia & Hydro-ethanolic & 1.71 & 0.91 \\
& Aqueous & 0.61 & 0.80 \\
\hline
\end{tabular}

(Alkali et al. 2015) showed low yields for the methanolic extract compared to the yields of the extractions in our study for I. asrifolia. On the other hand, for C. diffusa and $E$. indica, the works of (Khan et al. 2011) and Morah and Odey (2020) respectively obtained higher yields than those obtained in our study. This variability could be justified by the type of extract, the solvents used and the collection site of the medicinal plants. Indeed, the work of (Badiaga 2011) shows that the phytochemical constituents of medicinal plants vary from one region to another and this is according to the location, the nature or the nutritional richness of the soil and the climate. This could be the basis for the difference in yield rates obtained.

Phytochemical analyses have shown a diversity of secondary metabolites of these plants: flavonoids, mucilages, coumarins, tannins, anthocyanins, leucoanthocyanins and anthraquinones. Secondary metabolites are important in that they participate in the relationship life of the plant and play very varied roles. This could justify the diversity of secondary metabolites identified in each plant. Phytochemical screening of the whole plant of A. ciliata revealed the presence of anthraquinones, leucoanthocyanins, flavonoids and mucilages. In contrast to the present study, the work of Okoronkwo et al. (2015) did not identify flavonoids in the leaves of this plant. But the latter identified alkaloids, tannins and saponins in significant amounts, which was not the case in our study. According to Odeja et al. (2016), preliminary phytochemical screening performed on several types of extracts (hexane, ethyl acetate, methanol) revealed the presence of alkaloids, saponins, flavonoids, tannins, reducing sugars, phenols, glycosides and resins. In the methanolic extract of this plant, saponins, tannins, alkaloids, reducing sugars, phenols, glycosides and resins were identified. The ethyl acetate extract shows only alkaloids while the hexane extract shows the presence of alkaloids and flavonoids. The results obtained by these (Odeja et al. 2016) with the different extracts used are similar to those obtained in this study. The diversities obtained would certainly be due to the collection sites of the plants. Phytochemical study of Commelina diffusa showed the presence of anthraquinones, leucoanthocyanins, flavonoids, mucilages, catechic tannins and gall tannins. A previous study revealed the presence of glycoside, flavonoid, sterol, terpenoid, tannin, alkaloid, anthraquinone and others (Khan et al. 2011; Nasrin et al. 2019). Glycosides, sterols and terpenoids were not screened for in the present work. In another study, phytochemical screening of $C$. diffusa extracts revealed the presence of various phytochemicals such as alkaloids, phenolic compounds, tannins, steroids, flavonoids, proteins and phytosteroids. These authors also observed that the 
chemical components vary from one extract to another, depending on the solvents used (Malarvizhi et al. 2019). Regarding Eleusine indica, only three secondary metabolites were identified: reducing compounds, flavonoids and mucilages. In one study, gas chromatography-mass spectroscopy analysis of Eleusine indica leaf essential oil showed the presence of twentyseven organic compounds. Eleven of them are hydrocarbons while the remaining thirteen are oxygenates (Peñaloza et al. 2018). Among the compounds identified by these authors are pirotoxin, 3,6,10-trimethylpentadecane, nordecane, tert-hexadecanethoil, 2-melthylhexa decan-1ol, nonadecane, 2,6,10,14-tetramethylpentadecane and heptacosane. In the 1970s, flavonoids were detected by paper chromatography in the aerial parts of E. indica. Schaftoside and vitexin were also identified (Peñaloza et al. 2018). Phytochemical screening of I. asarifolia leaves detected anthocyanins, anthraquinones, flavonoids, mucilages, coumarins and tannins. The work of Furtado et al. (2016) identified phenols, tannins, alkaloids, saponins and flavonoids. According to Jegede et al. (2009), the methanol leaf extract of this plant contains saponin, tannin, alkaloid and phenol.

Furthermore, according to Kouchadé et al. (2017), phenolic compounds and phenols including flavonoids, tannins, coumarins, anthocyanins, leucoanthocyanins and quinones present in medicinal plants are natural antioxidants. These compounds are able to interfere with free radicals generated by the human body or formed in response to environmental aggressions (pollutants, infections). Among these chemical compounds, flavonoids possess several biological properties, including strong antiparasitic and antibacterial activity (Soré et al. 2018; Rahmouni 2019). Flavonoids being identified in all studied medicinal plants could explain the diversity of biological properties of these plants used against several diseases in Benin. As for coumarins, they possess anti-inflammatory, antiseptic, antifungal and antibacterial properties (Fagbohun et al. 2012; Kouchadé et al. 2017). These compounds could be responsible for the biological activities attributed to these plant species. Also, none of the plants studied have the alkaloids and cyanogenic derivatives as secondary metabolites. Cyanogenic derivatives are true poisons to human cells according to Adjatin et al. (2013). The absence of this metabolite from these medicinal plants can reassure traditional healers and consumers of the risks associated with the toxicity on the body of these plant species. On the other hand, according to Belila Ounis (2018), alkaloids possess a wide spectrum of biological activities including anti-malarial and antibiotic properties as well as analgesic and spasmolytic properties. According to Degla et al. (2021), variation in the intrinsic and geo pedological factors of the plants would be responsible for the variation in the antiparasitic effect of the secondary metabolites of these plants. These various plants with interesting properties could be an alternative solution against parasitic and microbiological infestations in humans and animals (Degla et al. 2021). It is therefore important to verify the safety of these plants for a better use.

From the results of the larval toxicity, it appears that all extracts have an $\mathrm{LC}_{50}$ greater than $0.1 \mathrm{mg} / \mathrm{mL}$, the concentration at which medicinal plant extracts are considered non-toxic. Several works have proven the relevance of the larval toxicity test in preliminary toxicity studies (Quignard et al. 2003; Agbodjento et al. 2020). A positive correlation has even been demonstrated between the larval toxicity test and the lethal oral dose of medicinal plants in mice (Lagarto Parra et al. 2001). Moreover, there is a correlation between larval toxicity and toxicity on human cells, namely 9PS and 9KB cells of human nasopharyngeal carcinoma on the one hand, and A-549 cells of lung carcinoma and HT-29 cells of colon carcinoma on the other hand (Carballo et al. 2002). All these data show that the absence of toxic effect of the extracts of the studied plants rules out any argument of presumption of toxicity of these plants. Moreover, the results of the phytochemical screening carried out on all the plants showed a total absence of cyanogenic derivatives in all the plants. Cyanogenic derivatives are real poisons for human and animal cells (Adjatin et al. 2013). These data once again confirm the lack of toxic effect of the plants studied. Although the toxicity test on the Artemia salina model is a preliminary screening to determine the degree of cytotoxicity of the plants, these data open a great prospect for further toxicological studies on another model or a whole animal to determine the acute and chronic toxicity of these medicinal plants. However, according to the work of Alfarisi et al. (2020), the ethanolic extract of $A$. ciliata does not show acute toxicity effect on female wistar rats. Aqueous extract of $C$. diffusa does not show cytotoxic effect on brine larvae (Nasrin et al. 2019). This plant protects wistar rats from gentamicin-induced nephrotoxicity and shows no acute and subacute toxicity effects (Esom-Ibe et al. 2018; Djoko et al. 2020). E. indica exhibits low cellular toxicity and no acute toxicity effects (Adoho et al. 2021). The results of this work are similar to that of Bezerra et al. (2017). These authors reveal that the infusion of the leaves of $H$. suaveolens do not cause any toxicity on the larvae of Artemia salina. In view of the usefulness of these plants in Beninese traditional medicine, it would be primordial and important to evaluate the toxicity of these plants on several laboratory models in order to valorize them on a scientific level.

\section{Conclusion}

This study determined the secondary metabolites contained in I. asarifolia, C. diffusa, A. ciliata and E. indica. At the end of this study, it was found that these plants contain several groups of secondary metabolites including flavonoids, mucilages, coumarins, tannins, anthocyanins, leucoanthocyanins and anthraquinones. These plants also show no cytotoxic effect at the concentrations tested. Indepth studies of quantitative chemical characterization and toxicity evaluation on an animal model are necessary for an optimal valorization of these plants.

\section{Author's Contribution}

ACCA, BBSK, PAO and EVBA conceptualized the idea and finalization of edits, analyzed and interpreted the data. ACCA, PAO and EVBA performed the experiment and collected the data. ACCA, BBSK and PAO Provided support in the conceptualization of the research design, wrote and edited the manuscript. MSH-A and ABG participated in supervision. All authors participated in reading and editing the manuscript. 


\section{REFERENCES}

Adjatin A, Dansi A, Badoussi E, Loko Y, Dansi M, Azokpota P, Gbaguidi F, Ahissou H, Akoègninou A and Akpagana K, 2013. Consumed as vegetable in Benin. International Journal of Current Microbiology and Applied Sciences 2: 1-13.

Adoho ACC, Zinsou FT, Abiodoun P, Olounlade EVBA, Hounzangbe-Adote MS and Gbangboche AB, 2021. Review of the literature of Eleusine indica: phytochemical, toxicity, pharmacological and zootechnical studies. Journal of Pharmacognosy Phytochemistry 10: 29-33. https://doi.org/ 10.22271/phyto.2021.v10.i3a.14060

Agbodjento E, Klotoé J, Sacramento T, Dougnon T, Déguenon E, Agbankpé J, Fabiyi K, Assogba P, Hounkanrin M-P and Akotegnon R, 2020. Larval cytotoxic and subacute toxicity of Gardenia ternifolia, Rourea coccinea, and Cassytha filiformis used in traditional medicine of Benin (West Africa). Journal of Toxicology 2020: 1-11. https://doi.org/ 10.1155/2020/8843575

Al-Zubairi AS, Abdul AB, Abdelwahab SI, Peng CY, Mohan S and Elhassan MM, 2011. Eleucine indica possesses antioxidant, antibacterial and cytotoxic properties. Evidence-Based Complementary Alternative Medicine 2011: 1-6. https://doi.org/10.1093/ecam/nep091

Alfarisi H, Subangkit M, Sa'diah S and Wresdiyati TJJKHS, 2020. Acute toxicity test of ethanolic extract of Acalypha hispida leaves in female rats: a physiological and histological study. Jurnal Kedokteran Hewan 14: 48-53. https://doi.org/ 10.21157/j.ked.hewan.v14i3.16176

Alkali Y, Gana A, Abdulkadir A and Humphrey NC, 2015. Trypanocidal efficacy of two indigeneous ethanolic plant extracts (Mimosa pigra and Ipomoea asarifolia) against Trypanosoma evansi phospholipase A2 activity. Journal of Acute Diseases 4: 28-31. https://doi.org/10.1016/S22216189(14)60078-0

Angone SA, Mewono L, Mounanga MB, Medzegue S, Mendene HE, Ndong JM, Siawaya JD and Souza A, 2013. Phytochemical screening and cytotoxicity studies of Chrysophyllum pruniforme Pierre ex Engl. barks. Pharmacognosy Research 5: 195-199. https://10.4103/0974$\underline{8490.112427}$

Badiaga M, 2011. Etude ethnobotanique, phytochimique et activités biologiques de Nauclea latifolia Smith, une plante médicinale africaine récoltée au Mali. Université Blaise Pascal-Clermont-Ferrand II, Retrieved from https://tel.archives-ouvertes.fr/tel-00719564/

Belila S and Ounis Z, 2018. Contribution à l'étude phytochimique et biologique des alcaloïdes de la partie aérienne de Pergularia tomentosa L. University of Eloued DSpace, Retrieved from http://dspace.univ-eloued.dz/handle/ $\underline{123456789 / 1081}$

Bezerra JWA, Costa AR, da Silva MAP, Rocha MI, Boligon AA, da Rocha JBT, Barros LM and Kamdem JP, 2017. Chemical composition and toxicological evaluation of Hyptis suaveolens (L.) Poiteau (LAMIACEAE) in Drosophila melanogaster and Artemia salina. South African Journal of Botany 113: 437-442. https://doi.org/10.1016/j.sajb.2017. $\underline{10.003}$

Biu A, Buratai L, Onyedim P, Hambali I, Ngulde S, Zakariah M and Lawal J, 2016. Phytochemistry, toxicity and in vitro antitrypanosomal efficacy of crude aqueous extract of Guiera senegalensis stem bark. Bangladesh Journal of Veterinary Medicine 14: 93-97. https://doi.org/10.3329/ bjvm.v14i1.28831

Carballo JL, Hernández-Inda ZL, Pérez P and García-Grávalos MD, 2002. A comparison between two brine shrimp assays to detect in vitro cytotoxicity in marine natural products. BMC Biotechnology 2: 1-5. http://www.biomedcentral.com/ $\underline{1472-6750 / 2 / 17}$
Cooper EL, 2004. Complementary and alternative medicine, when rigorous, can be science. eCAM 1: 1-4.

Dah-Nouvlessounon D, Adoukonou-Sagbadja H, Diarrassouba N, Sina H, Adjanohoun A, Inoussa M, Akakpo D, Gbenou JD, Kotchoni SO and Dicko MH, 2015. Phytochemical analysis and biological activities of Cola nitida bark. Biochemistry Research International 2015: 1-13. https://doi.org/10.1155/ 2015/493879

Degla L, Kuiseu J, Olounlade P, Attindehou S, HounzangbeAdote M, Edorh PA and Lagnika L, 2022. Use of medicinal plants as alternative for the control of intestinal parasitosis: assessment and perspectives. Agrobiological Records 7: 1-9. https://doi.org/10.47278/journal.abr/2021.011

Djoko SK, Nchouwet ML, Kamani SLP, Kodjio N, Kamanyi A and Ngnokam SLW, 2020. Extracts from commelina diffusa protect against gentamicin-induced nephrotoxicity in wistar rats. Saudi Journal of Biomedical Research 5: 61-68. https://doi.org/10.36348/sjbr.2020.v05i04.007

Elghobashy KA, Eldanasoury MM, Elhadary AA and Farid M, 2020. Phytochemical constituent, HPLC profiling and antioxidant activity of Passiflora incarnata and Arctium lappa leaves extracts. International Journal of Veterinary Science 9: 4249.

Esom-Ibe A, Ebong O and Aprioku J, 2018. Acute and sub-acute toxicity evaluation of Commelina benghalensis (Commelinacaea) and Newbouldia laevis (Bignoniaceae) ethanol leaf extracts in wistar rats. Journal of Advances in Biology Biotechnology 17: 1-9. https://doi.org/10.9734/ $\mathrm{JABB} / 2018 / 40523$

Fagbohun E, Lawal O and Ore M, 2012. The proximate, mineral and phytochemical analysis of the leaves of Ocimum gratissimum L., Melanthera scandens A. and Leea guineensis L. and their medicinal value. Portal Regional da BVS 3: 15-22.

Farida T, Salawu O, Tijani A and Ejiofor J, 2012. Pharmacological evaluation of Ipomoea asarifolia (Desr.) against carbon tetrachloride-induced hepatotoxicity in rats. Journal of Ethnopharmacology 142: 642-646. https://doi.org/10.1016/j.jep.2012.05.029

Furtado AA, Torres-Rêgo M, Lima MC, Bitencourt MA, Estrela AB, da Silva NS, da Silva Siqueira EM, Tomaz JC, Lopes NP and Silva-Júnior AA, 2016. Aqueous extract from Ipomoea asarifolia (Convolvulaceae) leaves and its phenolic compounds have anti-inflammatory activity in murine models of edema, peritonitis and air-pouch inflammation. Journal of Ethnopharmacology 192: 225-235. https://doi.org /10.1016/j.jep.2016.07.048

Ghorani-Azam A, Sepahi S, Riahi-Zanjani B, Ghamsari AA, Mohajeri SA and Balali-Mood M, 2018. Plant toxins and acute medicinal plant poisoning in children: A systematic literature review. Journal of research in medical sciences: the official journal of Isfahan University of Medical Sciences 23: 1-9. https://doi.org/10.4103/jrms.JRMS_629_17

Hosseinzadeh S, Jafarikukhdan A, Hosseini A and Armand R, 2015. The application of medicinal plants in traditional and modern medicine: a review of Thymus vulgaris. International Journal of Clinical Medicine 6: 635 https://doi.org/10.4236/ijcm.2015.69084

Jegede I, Nwinyi F, Ibrahim J, Ugbabe G, Dzarma S and Kunle $\mathrm{O}, 2009$. Investigation of phytochemical, anti-inflammatory and anti nociceptive properties of Ipomoea asarifolia leaves. Journal of Medicinal Plants Research 3: 160-165. https://doi.org/10.5897/JMPR.9000827

Khan MAA, Islam MT and Sadhu SK, 2011. Evaluation of phytochemical and antimicrobial properties of Commelina diffusa Burm. f. Oriental Pharmacy and Experimental Medicine 11: 235-241. https://doi.org/10.1007/s13596-011$\underline{0028-0}$

Klotoé JR, Agbodjento E, Dougnon VT, Yovo M, Sacramento TI, Déguénon E, Dougnon JT and Atègbo JM, 2020. 
Exploration of the chemical potential and antioxidant activity of some plants used in the treatment of male infertility in southern Benin. Journal of Pharmaceutical Research International 32: 1-12. https://doi.org/10.9734/j pri/2020/v32i 430418

Kouchadé SA, Adjatin AR, Adomou AC, Dassou HG and Akoègninou A, 2017. Phytochimiques des plantes médicinales utilisées dans la prise en charge des maladies infantiles au Sud-Bénin. European Scientific Journal 13: 471-488. https://doi.org/10.19044/esj.2016.v13n3p471

Lagarto Parra A, Silva Yhebra R, Guerra Sardiñas I and Iglesias Buela L, 2001. Comparative study of the assay of Artemia salina $\mathrm{L}$. and the estimate of the medium lethal dose (LD50 value) in mice, to determine oral acute toxicity of plant extracts. Phytomedicine 8: 395-400. https://doi.org/10.1078/ 0944-7113-00044

Lakmichi H, Bakhtaoui FZ, Gadhi CA, Ezoubeiri A, El Jahiri Y, El Mansouri A, Zrara I and Loutfi K, 2010. Toxicity profile of the aqueous ethanol root extract of Corrigiola telephiifolia pourr.(Caryophyllaceae) in rodents. Evidence-Based Complementary Alternative Medicine 2011: 1-10. https://doi.org/10.1155/2011/317090

Lish ADR, Johari SA, Sarkheil M and Yu IJ, 2019. On how environmental and experimental conditions affect the results of aquatic nanotoxicology on brine shrimp (Artemia salina): A case of silver nanoparticles toxicity. Environmental Pollution 255: 113358. https://doi.org/10.1016/j.envpol. 2019.113358

Mahboubi M, Haghi G, Kazempour N and Hatemi AR, 2013. Total phenolic content, antioxidant and antimicrobial activities of Blepharis edulis extracts. Songklanakarin Journal of Science Technology 35: 11-16.

Malarvizhi D, Karthikeyan A, Sudan I and Satheeshkumar R, 2019. Phytochemical analysis of Commelina diffusa Burm. F. through GC-MS method. Journal of Pharmacognosy Phytochemistry, 8: 376-379.

Mohan E, Suriya S, Shanmugam S, Muthupandi C and Rajendran K, 2021. Preliminary phytochemical appraisal of selected medicinal plants. Journal of Drug Delivery Therapeutics 11: 56-58. https://doi.org/10.22270/jddt.v11i2-S.4646

Morah FN and Odey CO, 2020. Chemical composition and antimicrobial activity of Eleusine indica leaf essential oil. International Journal of Chemical Biochemical Sciences 18: 137-141.

Moshi MJ, Cosam JC, Mbwambo ZH, Kapingu M and Nkunya MH, 2004. Testing beyond ethnomedical claims: brine shrimp lethality of some. Tanzanian plants. Pharmaceutical Biology 42: 547-551. https://doi.org/10.3109/1388020049 $\underline{0897920}$

Mounanga MB, Mewono L and Angone SA, 2015. Toxicity studies of medicinal plants used in sub-Saharan Africa. Journal of Ethnopharmacology 174: 618-627. https://doi.org/10.1016/j.jep.2015.06.005

Nasrin M, Afroz F, Sharmin S, Rana MS and Sohrab MH, 2019. Cytotoxic, antimicrobial and antioxidant properties of Commelina diffusa Burm. F. Pharmacology Pharmacy 10: 82. https://doi.org/10.4236/pp.2019.102007

Neergheen-Bhujun VS, 2013. Underestimating the toxicological challenges associated with the use of herbal medicinal products in developing countries. BioMed research international 2013: 1-10. https://doi.org/10.1155/2013/804086
Neves RAF, Fernandes T, Santos LND and Nascimento SM, 2017. Toxicity of benthic dinoflagellates on grazing, behavior and survival of the brine shrimp Artemia salina. PloS One 12: e0175168. https://doi.org/10.1371/journal. pone. 0175168

Odebiyi O and Sofowora E, 1978. Phytochemical screening of Nigerian medicinal plants II. Lloydia 41: 234-246.

Odeja O, Ogwuche CE, Elemike EE and Obi G, 2016. Phytochemical screening, antioxidant and antimicrobial activities of Acalypha ciliata plant. Clinical Phytoscience 2: 12. https://doi.org/10.1186/s40816-016-0027-2

Okoronkwo NE, Mbachu KA, Nnaji AB and Igboanugo OS, 2015. Evaluation of chemical compositions and antimicrobial activities of Acalyphaciliata leaves. International Journal of Plant Sciences and Ecology 1: 6771.

Olusunle FD, Akharaiyi FC, Ogunmefun OT and Okiki PA 2019. Studies of the antibacterial, phytochemical, proximate and GC-Mass Spectrophotometric of Ocimum gratissimum Linn methanol leaf extract. International Journal of Veterinary Science8: 168-173.

Peñaloza E, Casanova LM, Leal IC, Aguiar PFd and Costa SS, 2018. Metabolite fingerprinting and profiling of the medicinal grass Eleusine indica based on HPLC-DAD, UPLC-DAD-MS/MS and NMR analyses. Journal of the Brazilian Chemical Society 29: 2522-2534. http://dx.doi.org/ 10.21577/0103-5053.20180131

Quignard ELJ, Pohlit AM, Nunomura SM, Pinto ACDS, Santos EVMD, Morais SKRD, Alecrim AM, Pedroso ACDS, Cyrino BRB and Melo CSD, 2003. Screening of plants found in Amazonas state for lethality towards brine shrimp. Acta Amazonica 33: 93-104. https://doi.org/10.1590/18094392200331104

Rahmouni M, 2019. Extraction et activité biologique de quelques principes actifs (flavonoïdes). Université Ahmed DraïaAdrar, Retrieved from https://dspace.univ-adrar.edu.dz /jspui/handle/123456789/2202

Rafay M, Ghaffar MU, Abid M, Malik Z and Madnee M, 2021. Phytochemicals analysis and antimicrobial activities of Echinops echinatus from Cholistan Desert, Pakistan Agrobiological Records 5: 21-27. https://doi.org/10.47278/ journal.abr/2021.001

Singh D, Raman M, Saradha V, Jayabharathi P and Kumar V, 2004. Acaricidal property of kuppaimeni (Acalypha indica) against natural Psoroptes cuniculi infestation in broiler rabbits. Indian Journal of Animal Sciences 74: 1003-1006.

Soré H, Sanon S and Hilou A, 2018. Antiplasmodial properties of plants isolated flavonoids and their derivatives. International Journal of Herbal Medicine 6: 43-56.

Tine Y, Diop M, Ndoye I, Diallo A and Wele A, 2019. Revue bibliographique sur la composition chimique et les activités biologiques de Guiera senegalensis JF Gmel (Combretaceae). International Journal of Biological Chemical Sciences 13: 3449-3462. https://doi.org/10.4314/ ijbcs.v13i7.37

Unuofin J, Otunola G and Afolayan A, 2017. Toxicity assessment of Kedrostis africana Cogn: a medicinal plant used in the management of obesity in South Africa using brine shrimp (Artemia salina Linn.) assay. International Journal of Pharmaceutical Science and Research 8: 3719-3725. 